\title{
A representação da morte infantil em imagens cemiteriais no Brasil (séculos XIX eXX)
}

\author{
The representation of death of children in Brazilian cemeteries \\ (nineteenth and twentieth centuries)
}

La muerte infantil en la representación de las imágenes en cementérios brasileños (siglos XIXyXX)

Alberto Gawryszewski $i^{*}$

\section{Resumo}

A questão central desenvolvida neste trabalho foi o uso de imagens de crianças (fotografias e estatutárias) encontradas em sepulturas de cemitérios brasileiros nos séculos XIX e XX. O uso de fotografias em túmulos ainda carece de maiores pesquisas. O objetivo é possibilitar ao leitor a abordagem histórica sobre um tema específico, oferecer uma perspectiva quanto à construção da memória da criança, seja pelas imagens ou pelos escritos. As cidades escolhidas são de diversas regiões para ajudar na demonstração de um possível padrão ou de afinidade com a temática da morte. As cidades em que se localizam os cemitérios e as datas das fotografias são cita- das, ocultando-se o nome do cemitério (quando possível) e o nome da família das crianças falecidas.

Palavras-chave: Adornos. Cemitério. Crianças. Imagem.
* Doutor em História Econômica pela Universidade de São Paulo, Brasil. Professor da Universidade Estadual de Londrina, Brasil. E-mail: agawry@sercomtel.com.br

Recebido em 01/04/2016 - Aprovado em 01/09/2016 http://dx.doi.org/10.5335/hdtv.16n.2.6919 


\section{Perspectivas}

A escolha da imagem, da frase ou dos objetos infantis para a sepultura não é gratuita, traz uma afetividade que comove. Não é só uma forma de amenizar a dor, mas de manter a lembrança dessa criança para os próximos e os distantes. Nesse sentido, é impossível ficar impassível diante de uma sepultura de uma criança, que é repleta de significados.

O familiar da criança morta deseja prestar uma homenagem e, ao mesmo tempo, tecer uma memória dos laços construídos. Essa memória é um fato social, temporal e espacial. Na maioria das vezes, há liberdade de escolha das narrativas, dos signos e das imagens, que podem trazer impressões sobre o infante morto, suas relações sociais, escolares e familiares.

Peter Burke (2000) procurou demonstrar como a fonte visual pode ser considerada evidência histórica, como ela foi usada nos últimos anos e, também, como é importante na construção do conhecimento histórico. O autor não deixou de chamar a atenção para os perigos da análise imagética sem embasamento teórico consistente. Mostrou, ainda, como as imagens constituem guias para o estabelecimento de novas concepções sobre doença e saúde, aparência, padrões de beleza e novos conhecimentos sobre a cultura material, suporte para a história das mentalidades, etc. Essas questões, como veremos, podem ser observadas nas imagens fotográficas cemiteriais infantis.

As imagens fotográficas não são consideradas verdades, elas devem ser analisadas em seu contexto histórico, pois são visões de um mundo passado, construções de uma memória, carregada de valores. No caso das fotografias cemiteriais, somam-se e potencializam-se valores religiosos.

Ciro Flamarion e Ana Mauad apresentaram suas visões sobre a importância da fotografia como fonte histórica, e é interessante percebermos o quanto suas perspectivas muito bem se encaixam neste trabalho:

É indiscutível a importância da fotografia como marca cultural de uma época, não só pelo passado ao qual nos remete, e principalmente, pelo passado que vem à tona. Um passado que revela, através do olhar fotográfico, um tempo e um espaço que fazem sentido. Um sentido individual que envolve a escolha efetivamente realizada; e outro, que remete o sujeito à sua época (1997, p. 406).

Kossoy afirma que a imagem pouco ou nada diz, ou mesmo emociona, àqueles que nada sabem do contexto histórico particular que a originou. No caso das fotografias utilizadas neste trabalho, o observador apenas sabe que se trata de um morto. A partir disso, apontamos para uma perspectiva distinta: há razão para a emoção e/ou lamento, mesmo de sujeitos (passantes) não relacionados ao túmulo observado, em especial se esse for de uma criança, adolescente ou jovem e no qual esteja inscrito um epitáfio igualmente emotivo. Trata-se, talvez, de uma nova abordagem teórica da fotografia.

Na mesma obra, Kossoy afirma que:

Toda fotografia é um resíduo do passado. Um artefato que contém em si fragmento determinado da realidade registrada fotograficamente. Se, por um lado, este artefato nos oferece indícios quanto aos elementos constitutivos (assunto, fotógrafo, tecnologia) que lhe deram origem, por outro o registro visual nele contido reúne um inventário de informações acerca daquele preciso fragmento tempo/espaço retratado (2009, p. 46-47). 
Interessa-nos sobremaneira a ideia da segunda parte dessa transcrição, ou seja, o inventário de informações contidas. Bem verdade que não desprezamos a primeira perspectiva, pois o processo das imagens cemiteriais está se modificando: os velhos retratos em preto e branco justapostos em medalhões de porcelana e envoltos em bronze estão cedendo espaço para imagens coloridas em novos suportes, possibilitados pelas novas tecnologias, também devido às razões econômicas e ao furto das peças metálicas, em especial do bronze.

Um importante diferencial da fotografia cemiterial em relação às demais é a impossibilidade de essa ser vista pelo fotografado, ao menos no uso na sepultura, é claro. Uma imagem é baseada na tríade fotografado-fotógrafo-observador, segundo a maioria dos estudos. Entretanto, a imagem cemiterial é considerada de outro modo. Nesse caso, um observador (um familiar, por exemplo) escolheu a fotografia como fonte de memória e recordação, formando-se uma dupla. Portanto, o observador passa a "autor", ser atuante; o fotografado, torna-se um ser passivo (caso não tenha escolhido a fotografia ainda em vida para ornamentar a sepultura) e o passante transforma-se em observador. Podemos acrescentar também o espaço físico em que se encontra a fotografia: o cemitério. Um espaço público que recebe a visita de pessoas que não tiveram nenhum contato com o falecido. Mas, tratando-se de uma criança, é quase impossível ficar impassível diante da fotografia no túmulo. Estamos, portanto, diante de um grande diferencial no mundo da imagem.

Compreendemos que os vivos deixam impressões sobre si e sobre os mortos. Pro- duzem seus próprios documentos, dando significados e sentido à vida. Todos os indivíduos representam seus sentimentos, sua sensibilidade, suas aspirações sociais e coletivas, sejam vinculadas às relações humanas terrenas ou a "celestiais". Segundo pesquisadores cemiteriais, as fotos e as esculturas buscam tornar presente o ausente.

\section{Algumas premissas}

Partimos de algumas premissas para compreendermos nosso objeto. Em primeiro lugar, vemos o cemitério como um local privilegiado para a construção de uma memória local, de manutenção de costumes e tradições. Em segundo lugar, ideia vinculada à primeira, esse é um local de defesa da perenidade, da infinitude do morto ou da sua vida. Os dados do falecido, por meio de dizeres e/ou de imagens, também são uma memória exposta, destinada aos passantes, dando o posicionamento dos vivos, e dos mortos, sobre a vida e a morte. Em terceiro lugar, temos clareza de que o cemitério reflete a sociedade, os estratos sociais, as crenças e os valores culturais, morais, éticos e religiosos, enfim, os valores socialmente aceitos (que podem variar ou não com o tempo). Considerando tais premissas, partimos para outra, a de imagens (fotografias e estatuária) e narrativas dos epitáfios que ajudam a compreender permanências e mudanças, não só em relação à vida ou à morte, mas sobre a cultura material, os padrões de beleza, as relações humanas, de parentesco, de valorização de determinadas carreiras profissionais, entre outros aspectos, enfim, de valores e ideias socialmente aceitas. Assim, o padrão 
da pose também é convencionalmente aceito. Desse modo, acreditamos que o cemitério estaria dentro do que Fabris (1998) chamou de "circuito social da fotografia", ou seja, um local de consumo da imagem.

\section{A fotografia: origens e seu ingresso nos cemitérios brasileiros}

A fotografia, em sua forma primitiva, foi publicizada por Louis Daguerre no ano de 1839, na França. No Brasil, o daguerreótipo chegou em 1840, ou seja, imediatamente após sua invenção, caindo nas graças do imperador D. Pedro II e de sua família, o que ajudou ainda mais na sua difusão pelas nossas terras. Relatos do final do século XIX dão conta da existência de dezenas de fotógrafos estabelecidos e de outros tantos ambulantes (às vezes, ambos mantendo relações profissionais). Kossoy (2002, p. 28) escreve que outras profissões eram exercidas paralelamente (dentistas, relojoeiros, comerciantes, entre outras atividades) como forma de sobrevivência desses fotógrafos. Portanto, é importante perceber o seu uso imediato na construção da memória.

No Brasil, nas visitas realizadas, pôde-se perceber a entrada da fotografia nos cemitérios brasileiros, como ornamento e como forma de memória familiar, somente na primeira década do século $X X$. A razão ainda não foi compreendida, mas constatou-se que tais imagens estavam ligadas às famílias com recursos financeiros para arcar com a manutenção do mausoléu e com a confecção da foto.

O trabalho de Tânia Andrade Lima (1994) é muito interessante, mesmo não pes- quisando o uso de fotografias cemiteriais, pois a autora observou as mudanças nos padrões no interior dos cemitérios com a transformação política e econômica que ocorreu no fim do século XIX e início do século XX, na cidade do Rio de Janeiro. Essas transformações, ainda a serem estudadas, permanecem até hoje, permitindo-nos entender o espaço cemiterial como espaço vivo. Lima dividiu a pesquisa em três momentos: padrão inaugural (1850-1888), padrão de transição (18891902) e padrão de consolidação (1903-1930). No primeiro período, as representações da morte são escatológicas, macabras e mórbidas, e assim seus símbolos remetem aos fins dos tempos (cobra que morde o próprio rabo, foices, ampulhetas aladas, entre outras representações). O branco domina no local em que os mortos dormem o sono da esperança, pois o cemitério é o espaço do silêncio, dos olhos fechados. Os mausoléus da ordem escravocrata representam a autopromoção, com os epitáfios expressando sua posição de privilégio.

O segundo período/padrão, conforme Lima, corresponderia à emergência de uma nova ordem, a capitalista. No cemitério, ocorre o empobrecimento da arquitetura tumular, as representações escatológicas são substituídas pelo signo da cruz, singelo, acompanhado por pequeno livro aberto ou pergaminho. Uma produção massificada, padronizada, pouco criativa. Destaca-se a presença da ideologia positivista, ainda merecedora de um estudo mais aprofundado na arte tumular.

Por fim, o último padrão ocorre em um período de reativação econômica. A atenção da burguesia volta-se para o cemitério, onde investe maciçamente, introduzindo novos 
materiais na arquitetura tumular, tal como o bronze, e conquistando seu espaço, demonstrando seu poder e reforçando sua memória com mausoléus monumentais. É neste momento que vamos encontrar um novo instrumento de memória, de ornamentação: a fotografia, feita por fotógrafo profissional.

Mas, antes da entrada da fotografia cemiterial, a imagem do morto era representada na forma de busto, relevo facial ou de corpo inteiro, compondo a estatuária da sepultura. Com nosso objeto de estudo, a criança, também foi assim.

\section{Amemória de crianças em cemitérios}

Antes de adentrar na questão da fotografia infantil propriamente dita, tratar-se-á de duas questões pertinentes, muito relacionadas: primeiramente, o espaço cemiterial infantil e em segundo lugar, a morte infantil. Quanto ao primeiro aspecto, verificamos que em diversos cemitérios visitados no Brasil (de norte a sul) há (havia) áreas exclusivas destinadas aos túmulos infantis. Qual a razão dessa separação? Isso se deve à necessidade de atender à demanda por espaço para o sepultamento de crianças, visto que morriam em grande maioria. Por isso, foram destinados três espaços específicos para esse fim. A leitura do Livro de Títulos de Catacumbas do Cemitério Municipal de Cascavel, na folha 3, do ano de 1959, por exemplo, esclarece que a maioria dos óbitos foi de crianças. Passados mais de cinquenta anos, porém, um novo quadro se apresenta. Com o deslocamento das famílias para outras localidades, a morte dos pais e demais parentes, a passagem do tempo propriamente dito, etc., muitos desses túmulos ficaram em completo abandono. Com a necessidade de espaços cemiteriais para novos enterramentos, os antigos, destinados às crianças, passaram a ser ocupados por novas sepulturas familiares. Portanto, toda essa documentação (dados, imagens, epitáfios, etc.) está sendo destruída.

No mapa do cemitério em questão (Figura 1), duas áreas marcadas por um círculo e uma estrela vazada mostram os espaços que antes eram ocupados por túmulos infantis; na outra área, demarcada com uma estrela cheia, já se iniciou o projeto de demolição dos túmulos infantis existentes.

Figura 1 - Planta baixa do Cemitério Municipal de

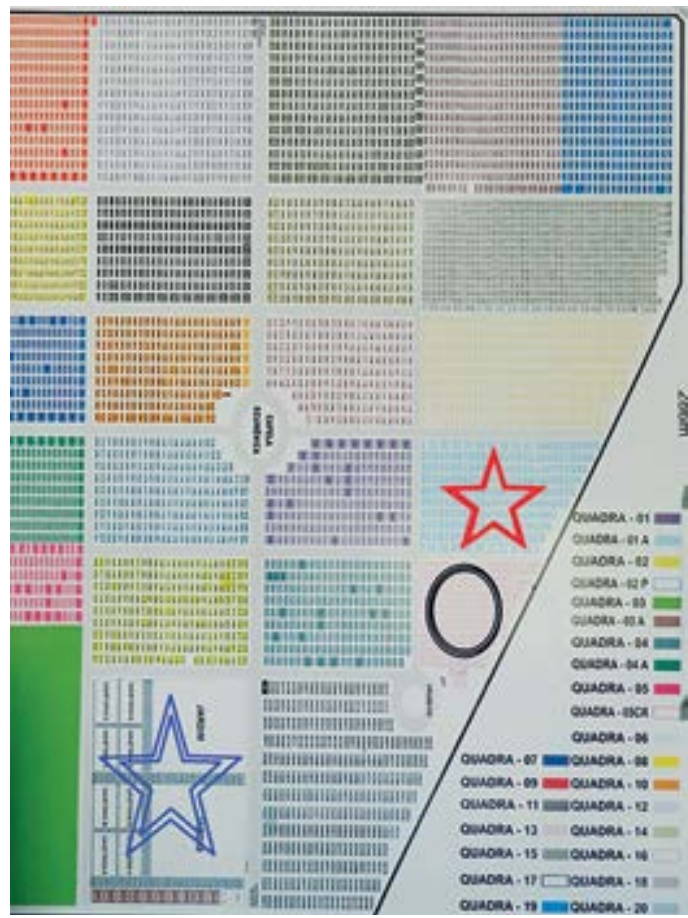

Fonte: arquivo pessoal do autor.

$\mathrm{Na}$ área remanescente, ainda se pode encontrar um pequeno número de fotos de 
crianças e ornamentações em estatuária, como da menina Mayara (Figura 2), cujo túmulo é único, pois é ornado com azulejos decorados com anjos, um forte significado religioso. Os pais abstiveram-se de fazer um epitáfio e colocar data: bastariam a imagem fotográfica e as imagens desenhadas? Ou tais informações estariam no azulejo destruído? Infelizmente, peças se perderam e lamenta-se o desaparecimento de vários túmulos originais como esse, que podem ter sido destruídos nesse único cemitério.

Figura 2 - Lápide de criança no Cemitério Municipal de Cascavel

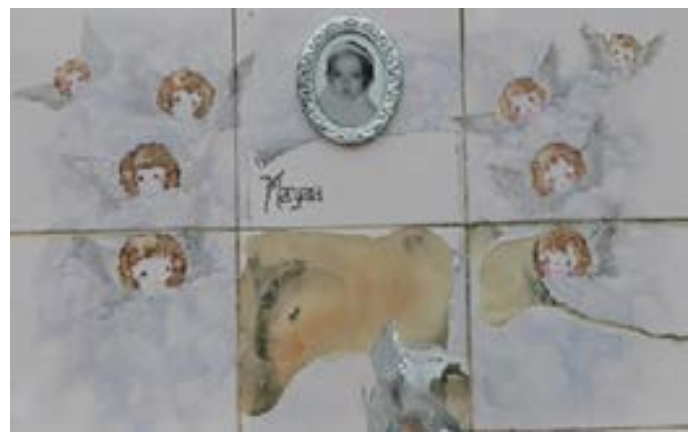

Fonte: arquivo pessoal do autor.

No cemitério de Foz de Iguaçu, constatou-se grande mortalidade infantil registrada nos livros de sepultamentos. Funcionários do local informaram que cerca de 6 mil sepulturas, exclusivas de crianças, já foram destruídas. Acredita-se que esse número esteja acima da realidade, embora não seja uma informação a ser desprezada. Ainda nesse cemitério, pode-se encontrar fileiras de sepulturas infantis.

No cemitério de São João Batista, cidade do Rio de Janeiro, é possível encontrar um setor destinado às crianças. Sobre esse ponto, Vailati escreveu:
De fato, no cemitério São João Batista, no Rio de Janeiro, se observa certa permanência - até as primeiras décadas - do costume em se concentrar conjuntamente os túmulos dos "anjinhos". A partir daí, não só a criança passou a ser enterrada de preferência junto à família, como em muitos casos ela ombreia com o pai-de-família como personagem símbolo dos jazigos familiares, informando a unicidade desse momento nas histórias dos comportamentos fúnebres (2010, p. 197).

As quadras destinadas às crianças, tanto no São João Batista como em cemitérios de várias regiões brasileiras, apontam que a prática de sepultura exclusiva para criança permaneceu por um período bem longo. Realmente, a incorporação da criança ao jazigo familiar aumentou, mas ainda hoje é possível verificar sepulturas exclusivas, em especial com a incorporação de novos hábitos, como a colocação de pertences da criança morta (brinquedos, escovas de cabelo, embalagens de produto de higiene, entre outros objetos), além de sua fotografia. Um aspecto a ser mencionado é a construção de sepulturas na cor rosa (meninas) e na cor azul (meninos).

Outra informação importante apontada por Vailati é sobre o espaço ocupado pela criança na vida e na morte na sociedade brasileira do século XIX, em especial, em relação ao conceitos relacionados à infância, muito relevantes para esta pesquisa, tais como "anjo" e "inocente". Vailati informa que a criança era portadora de uma natureza específica, daí, por exemplo, haver uma diferenciação entre a morte adulta e a morte infantil. Portanto, diferenças nos trajes, nos procedimentos de exposição e nas manifestações da morte. A criança morta era 
adjetivada como tal. Assim, o autor localiza expressões como "párvulo", "criança", "inocente" e "anjo". As duas primeiras significando criança, menino ou menina, com a idade de até sete anos (conferir discussão mais adiante). As duas últimas expressões

[...] trazem consigo significados que são fundamentais à caracterização da criança morta enquanto portadora de uma natureza diferenciada dos demais defuntos (VAILATI, 2010, p. 49).

Ambas as expressões estão relacionadas à criança morta, sendo a última comum até os dias de hoje.

A palavra inocente passou a figurar como importante elemento nos túmulos infantis. Em geral, antecedia o nome próprio da criança morta, apresentado de duas maneiras: isolado, em diminutivo (Arthurzinho, por exemplo), demonstrando afeição, ou incluindo os nomes dos pais. Algumas vezes, afirmava-se que era filho legítimo (Figuras 3 e 4$)$.

Figura 3 - Lápide em cemitério da Lapa, 1916

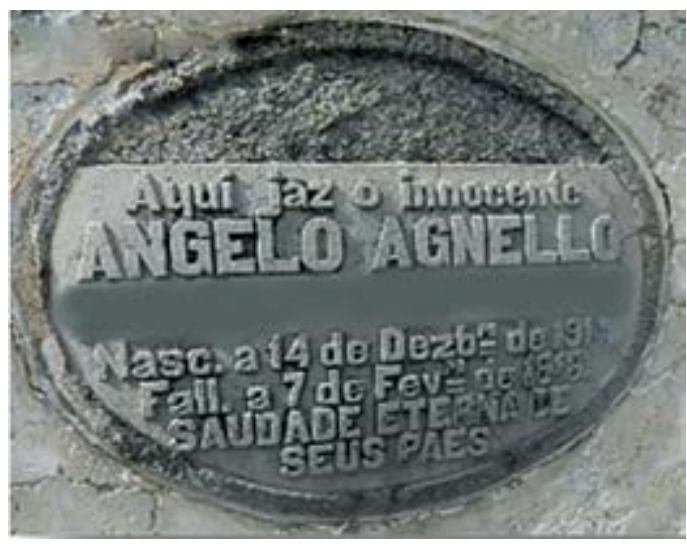

Fonte: arquivo pessoal do autor.
Figura 4 - Lápide em cemitério de Salvador, 1898

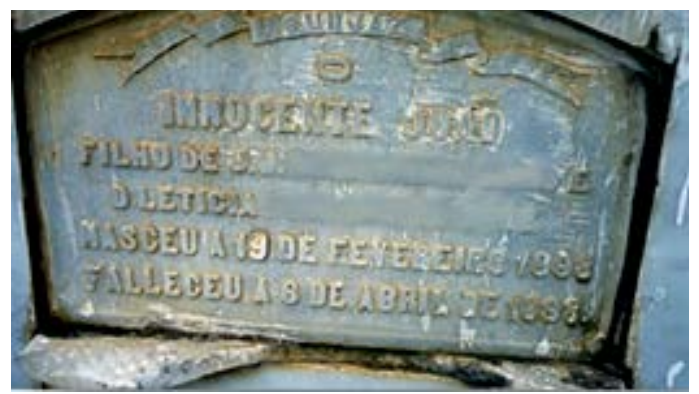

Fonte: arquivo pessoal do autor.

Vailati afirma que a expressão inocente estava vinculada à idade da criança morta. Esse ponto é importante, pois relaciona a forma como a criança era representada na imagem fotográfica, como veremos adiante. Os chamados anjinhos (ou anjos) também tinham relação com a idade. Conforme Valdez:

[...] os anjinhos eram qualquer criança que morresse até cerca de sete anos, idade máxima concedida aos não pecadores [...]. Por eles não se devia chorar para não molhar as asas do anjo que vinha recolher o anjinho. $\mathrm{O}$ normal era que se considerasse positiva a ida de mais um anjo para o céu para proteger os que aqui na terra permanecessem, ou para recebê-los no portal dos céus [...] (1999 apud BORGES, 2008, p. 119).

As Figuras 5 e 6 deixam claro que, em túmulos de crianças mortas no início do século $\mathrm{XX}$, temos a mesma simbologia. $\mathrm{Na}$ Figura 5, um anjo vem buscar outro "anjo", pois ao céu a criança está destinada, mãos em súplica, e outro anjo a recebe de braços abertos. Na Figura 6, um anjo chama ou vem ajudar uma criança (anjo) a subir as escadarias para o céu. Esse aspecto já foi levantado por Valdez (1999). Ainda durante o século XX, a morte infantil era vista como algo po- 
sitivo, mesmo com a carga de dor. Com a criança morta, em especial até a idade de sete anos, a família poderia contar, a partir de então, com um "anjo" próximo, um intercessor no mundo celestial. O uso da fotografia, nesse caso, passou a ter um significado importante, pois estaria exposta em local de destaque na casa, ao lado da imagem do santo preferido da família e/ou de Nossa Senhora ou de Jesus. Vailati, mais uma vez, nos dá a posição da medicina contra essa postura "positiva", já que a alta mortalidade infantil poderia comprometer o crescimento econômico da pátria. Inicia-se um combate nos meios políticos e acadêmicos, em especial pelas teses das faculdades de medicina. $\mathrm{O}$ médico José Pereira do Rego, Barão de Lavradio, em 1847, relatou o

[...] desprezo no princípio das moléstias da primeira infância, apresentando-se ao médico crianças já moribundas de gastro-enterites, hepatites e tubérculos mesentérios, julgando seus ignorantes progenitores ser uma felicidade a morte das crianças (apud VAILATI, 2010, p. 19).
Figura 5 - Lápide em cemitério de Porto Alegre, 1928

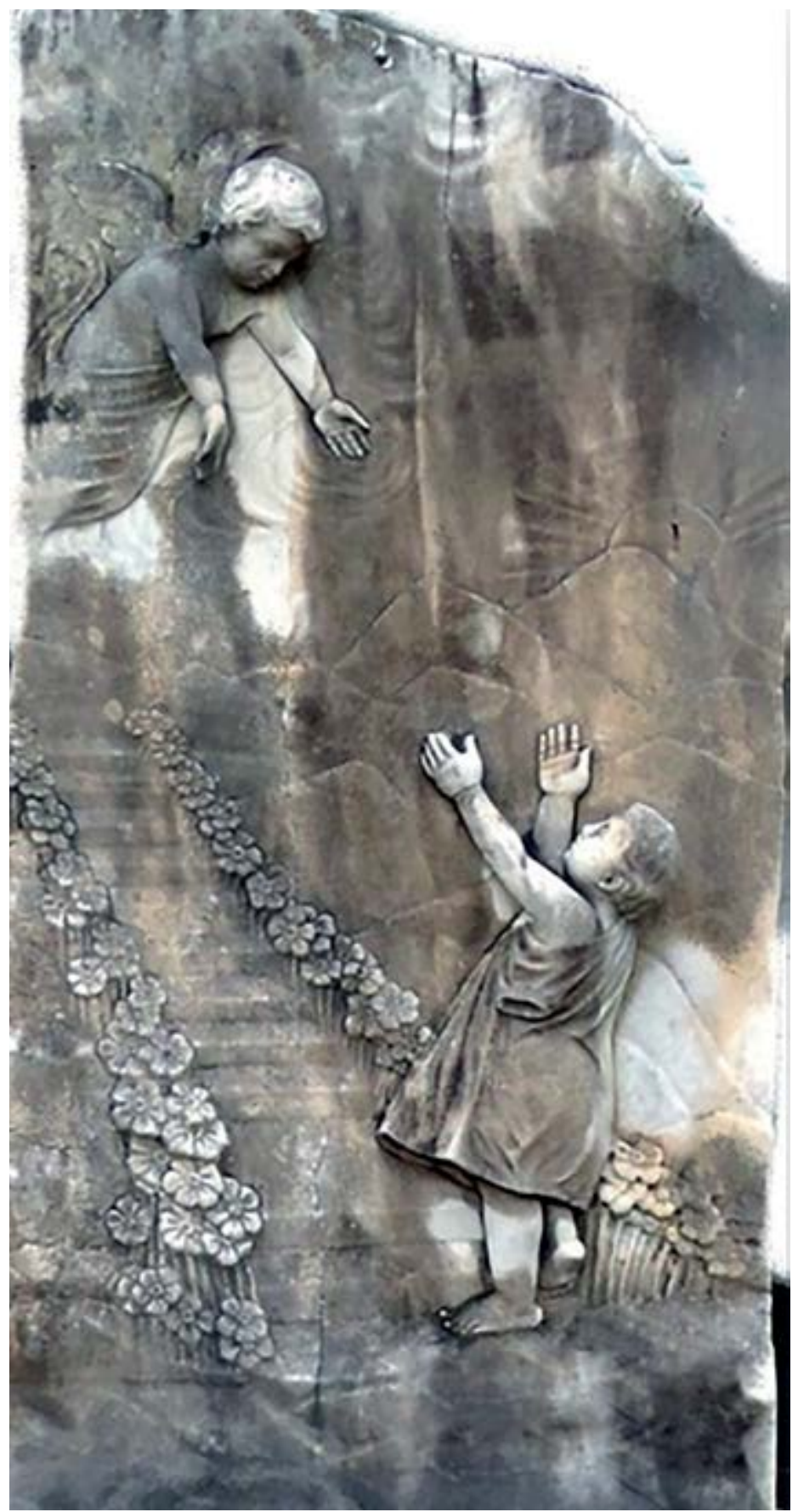

Fonte: arquivo pessoal do autor. 
Figura 6 - Lápide em cemitério de Caxias do Sul, sem data

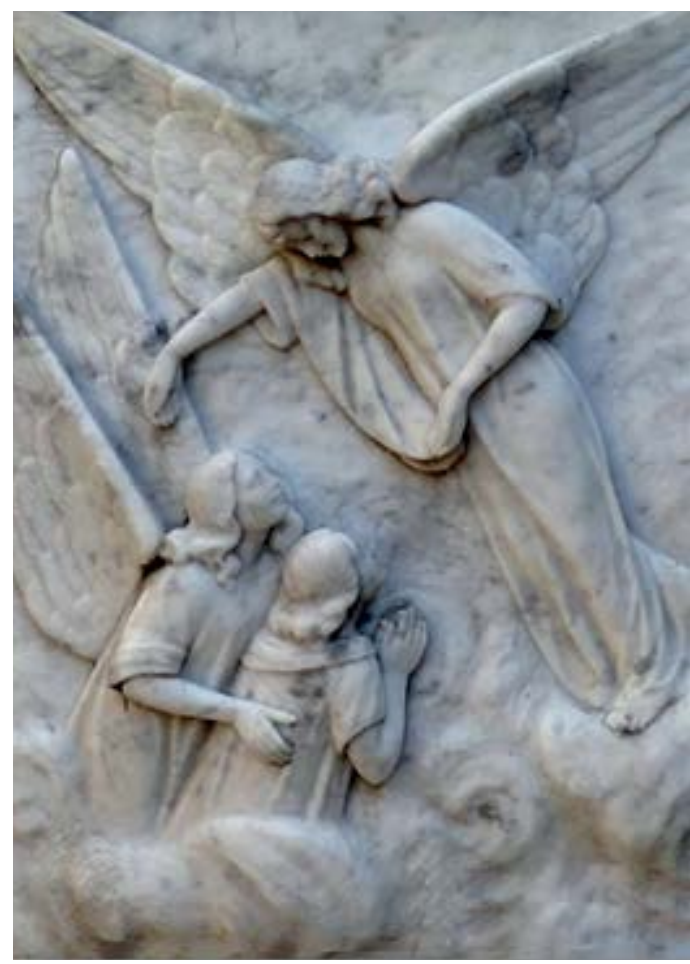

Fonte: arquivo pessoal do autor.

Patrícia Lavelle também afirma:

A imagem, mórbida estranha, não era incomum na segunda metade do século XIX. Era costume fazer retratar os 'anjinhos', isto é, as crianças que morriam pequenas, antes dos sete anos, ou então as jovens virgens, antes de casar. Por trás deste estranho hábito, delineia-se todo um culto da morte precoce, que tem o seu início ainda nos tempos coloniais com a idealização da criança morta, o 'anjinho' (2003 apud VAILATI, 2010, p. 206).

Portanto, é uma postura que veio dos tempos coloniais e que perdurou até a República. Em relação a essa problemática vinculada à idade, mais uma vez, Vailati nos ajuda a compreendê-la. Como já citado, havia uma diferença entre os procedimentos de vestir, velar, expor e enterrar adulto e criança. As idades de sete e doze anos, como os limites entre os mundos da criança e do adulto, foram determinantes, bem como a idade de até sete anos para definir uma criança como "inocente".

Em relação ao mundo do trabalho, conforme Vailati, a criança com sete anos ou mais, fora da classe dominante, já poderia nele ingressar. No âmbito da religião, ter "razão" ou "malícia" é o que determinaria o fim da infância. Ter razão ou malícia seria a capacidade de pecar. Portanto, a ideia de inocente estaria vinculada à pureza d'alma, da mesma forma, a inocência, ou "estado de inocência", estaria vinculada ao batismo, isto é, a não ter o pecado original. No contraponto, a idade de doze anos seria a plenitude da malícia, destaca-se que as meninas nessa idade já estariam prontas para o casamento (daí a primeira-comunhão ser na faixa dos oito aos dez anos, e não próximo ao matrimônio), enquanto os meninos entrariam nessa fase entre os 14 ou 15 anos.

Nesse mundo de crenças, é que a preparação do corpo para os procedimentos funerários da criança torna-se importante. Tal como o adulto, vestir o morto com a roupa apropriada seria uma forma de garantir a salvação da alma. No caso da criança inocente, na crença popular, já estaria garantida sua salvação. Daí a denominação de "anjo".

Claudia Rodrigues (1997) e Vailati (2010) apresentam informações valiosas sobre as mortalhas usadas, encontradas nos livros de assentamentos de óbitos, entre outros documentos. Vestimentas imitando santos e cores diferentes para meninos e meninas são os temas presentes. Em nosso caso, 
remetemo-nos às fotografias cemiteriais, que tiradas ainda em vida ou já após a morte, vão ornamentar as sepulturas no século $X X$.

A criança morta somente é fotografada após a toalete funerária, já pronta para o funeral. No caso em questão, fotografias do século XIX até meados do século XX, já com a mortalha escolhida e dentro do caixão. Pelas imagens coletadas, a roupa branca e a posição das mãos (postas em oração) passam a predominar. Por ser a imagem única da criança morta, a que vai para o álbum de família e/ou ornamentar a casa em local de destaque, junto com outros entes sagrados, seu preparo deve ser especial. Conforme Ana Mauad: "Fotografias de pessoas mortas, inclusive crianças, não eram raras em álbuns de familiares" (1999, p. 156). Em muitos casos, a fotografia aproximava o morto do parente distante, ou seja, daquele que não pôde comparecer ao ato fúnebre e que recebia uma lembrança do último momento do corpo na terra. Observa-se nesse conjunto de fotografias cemiteriais selecionadas para este trabalho a presença da mortalha virginal (branca), da coroa e do ramalhete de flores e das rendas, a vestimenta tradicional do século XIX, nas palavras de Vailati e Rodrigues (Figuras 7 a 9).

Figura 7 - Porto Alegre, 1937

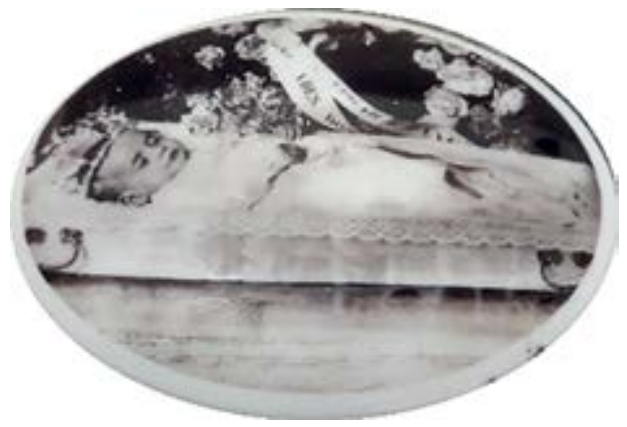

Figura 8 - Curitiba, 1909

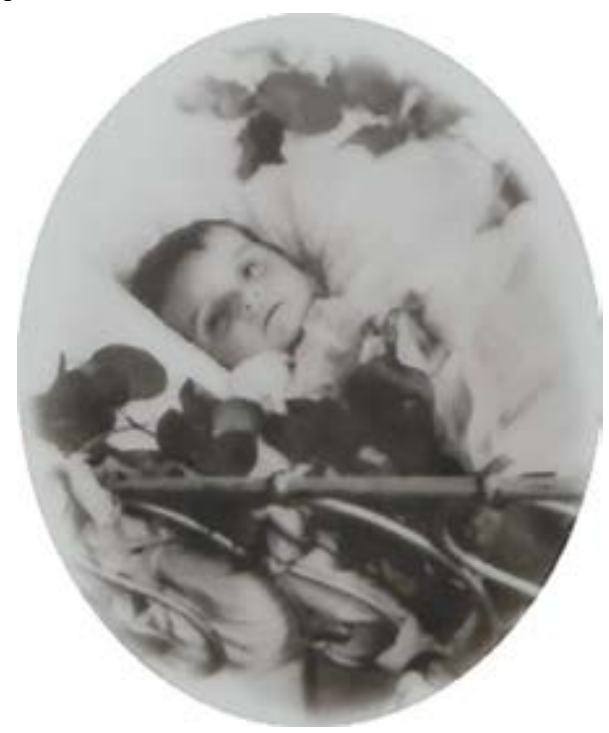

Fonte: arquivo pessoal do autor.

Figura 9 - Ornamento fotográfico tumular, Londrina, 1938

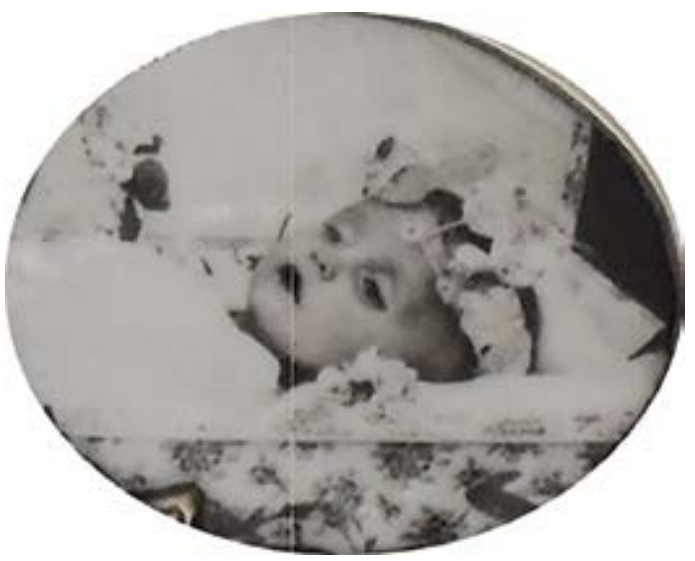

Fonte: arquivo pessoal do autor.

Fonte: arquivo pessoal do autor. 
Figura 10 - Foz do Iguaçu, 1978

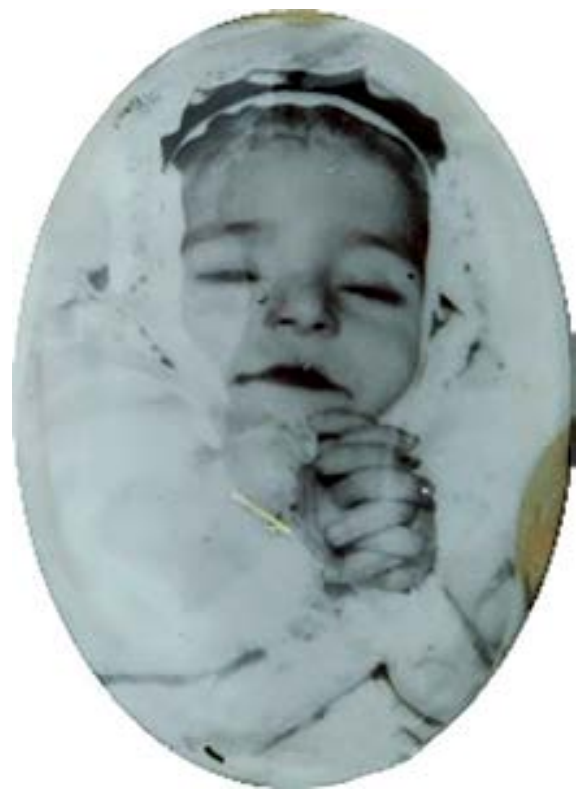

Fonte: arquivo pessoal do autor.

Figura 11 - Cáceres, 1957

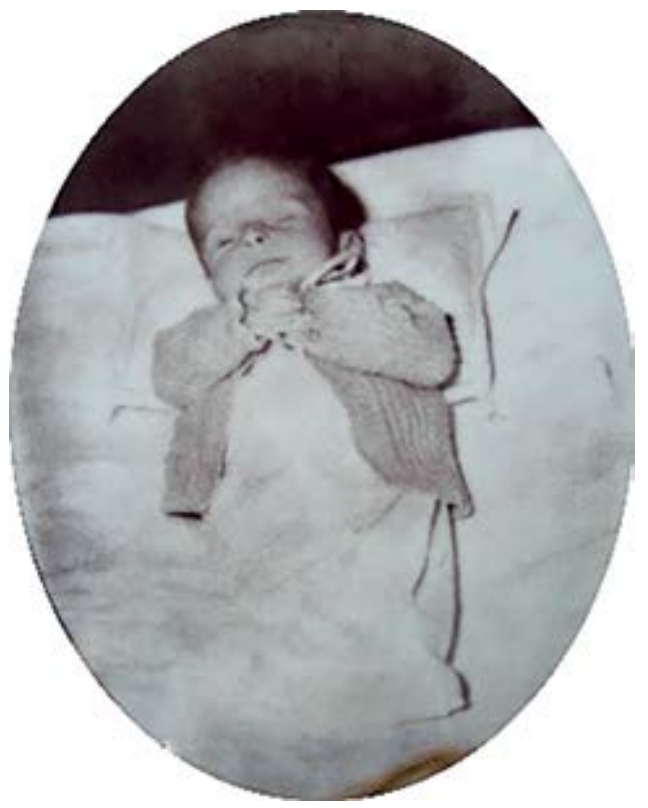

Fonte: arquivo pessoal do autor.
Nas Figuras 8 e 9, as crianças estão de olhos abertos. Havia (ou há ainda em alguns locais do Brasil) a crença popular de que as crianças deveriam ficar de olhos abertos para que pudessem encontrar o caminho do céu. Nas Figuras 7 e 9, as crianças já estão paramentadas dentro do caixão.

$\mathrm{Na}$ Figura 10, percebe-se ligeira mudança, roupa mais simples, embora branca, ausência do ramalhete e as mãos em postura de oração. Por fim, na Figura 11, a simplicidade, dedos entrelaçados e uma roupa branca e, por cima, um casaco. A fotografia foi colocada na vertical. Nesse sentido, é possível encontrar fotografias tiradas com a criança de olhos abertos, e, na ornamentação do túmulo, a fotografia é colocada na vertical, centralizando-se o rosto, o que causa a impressão de que a fotografia foi tirada em vida.

Essas imagens refletem o que foi descrito por viajantes e em manuais eclesiásticos usados por Vailati. Do grande volume de fotografias levantadas nos cemitérios brasileiros até o presente momento poucas foram as que se encaixavam nesse perfil, a maioria encontrada no sul do país.

Dona Menina, citada por Borges (2008, p.116), relembra com alegria a ocasião em que foi escolhida para representar o anjo no drama Santa Dorotéia. Diversas são as festividades católicas que ocorrem no Brasil em que crianças (meninas) são vestidas de anjo. Tais ocasiões merecem ser registradas nos álbuns de família. Poucos eram os retratos feitos pelas famílias, assim este acontecimento deveria receber atenção especial. A pose singela somada à vestimenta angelical, a tradição e a religiosidade popular, de considerar a criança como anjo, tornava 
essa fotografia propícia para ornamentar a sepultura.

Dever-se-ia lembrar da criança como um ser especial, uma pessoa boa, devota e, acima de tudo, um anjo. A partir de sua morte, ela passa a ser reconhecida, de fato, como um "anjo", moradora do paraíso. Curioso que no caso da Figura 12, a criança não se enquadra no padrão do século XIX, considerada como inocente, pois faleceu aos 13 anos. A idade está acima dos sete anos, mas a consideração dos pais é pela ausência de malícia na retratada. Assim pensaram muitos pais. Portanto, as fotografias nos apontam para uma nova definição, pelo menos etária, para o conceito de anjo. Na Figura 13, o "anjinho" tem ao seu pescoço a chupeta, reforçando sua pouca idade (2 anos). Por fim, na Figura 14, constata-se a preferência pelo enquadramento do rosto, realçando o ar angelical da fotografada.

Figura 12 - Ponta Grossa, 1949

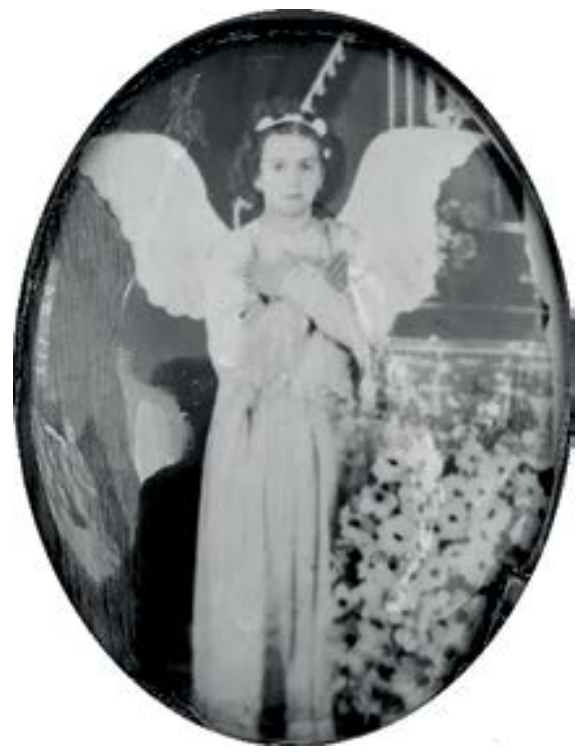

Fonte: arquivo pessoal do autor.
Figura 13 - Ponta Grossa, 1943

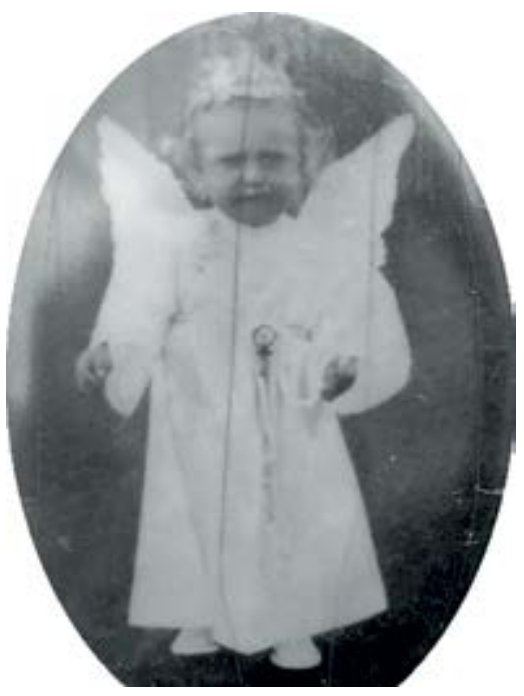

Fonte: arquivo pessoal do autor.

Figura 14 - Curitiba, sem data identificada

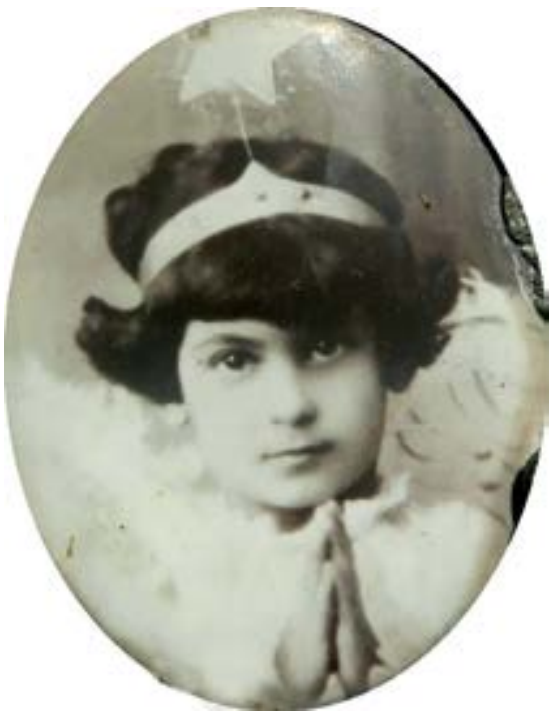

Fonte: arquivo pessoal do autor.

Em Clara dos Anjos, Lima Barreto descreveu o sincretismo religioso do povo do subúrbio carioca do início do século XX: para afastar os atrasos da vida, apelava-se 
para a feitiçaria, para uma rinite ou outra moléstia tenaz, procurava-se um espírita. Mas, em um ponto, observou o autor, todos estavam de acordo, em não deixar de batizar o filho ao nascer pelo ritual católico. Ao filho pagão não caberia o Céu e, portanto, ele jamais seria um anjo (BARRETO, [1980?], p. 35). Como o nascimento não mandava aviso e o batismo tinha que ser imediato, a fotografia nesse ritual não deveria ser comum.

A religiosidade não estava apenas na idade da inocência, pois outros rituais (além do batismo, como visto) apresentavam-se durante a vida. Um dos mais importantes era a primeira comunhão, entre os oito e doze anos. Por ser uma data solene e determinada, a contratação de um fotógrafo era mais fácil. A ausência de mais fotografias da criança falecida e/ou a importância do ritual da primeira comunhão faz com que, mesmo tendo passado anos do fato, a imagem do ato seja a escolhida pelos familiares, em especial os pais, para ornamentar o túmulo.

Nas Figuras 15 a 19, reproduz-se vários exemplos desse tipo de ornamento tumular. Uma imagem frontal (Figura 15), em que a jovem olha diretamente para o fotógrafo, em pose tradicional, com ou sem missal nas mãos, com as devidas vestimentas, conforme o sexo, ou seja, para meninos terno preto, camisa branca e braçadeira branca com laço (Figura 16 e Figura 17), e para as meninas a roupa branca com o véu (Figura 18). Essas são representações de devoção, de crianças que morreram, mas aprenderam o caminho correto da religião, provavelmente indicada por e para a alegria dos pais. Encontrou-se também em um mausoléu (capela-sepultura) uma moldura com o atestado de batismo da criança (Fi- gura 19). Talvez pela ausência da fotografia, que não acreditamos, o certificado comprova $\mathrm{o}$ ato religioso. Curiosamente, o falecido tinha 17 anos. Certamente esse tipo de fotografia é a maioria em referência ao ritual da vida.

Figura 15 - Rio de Janeiro, 1928

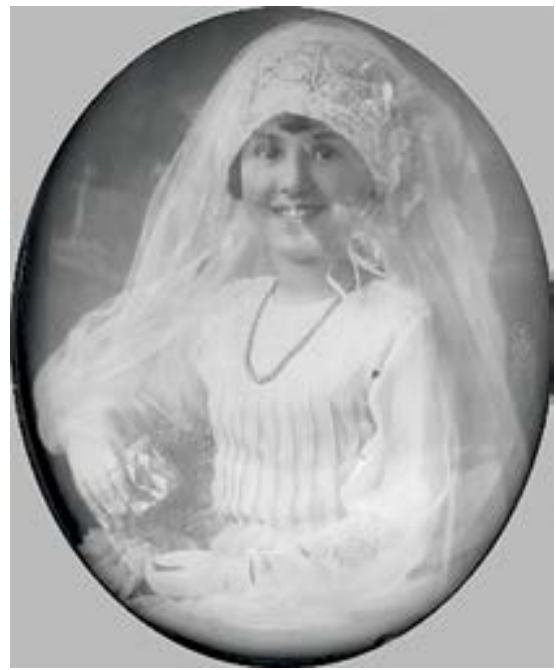

Fonte: arquivo pessoal do autor.

Figura 16 - Porto Alegre, 1927

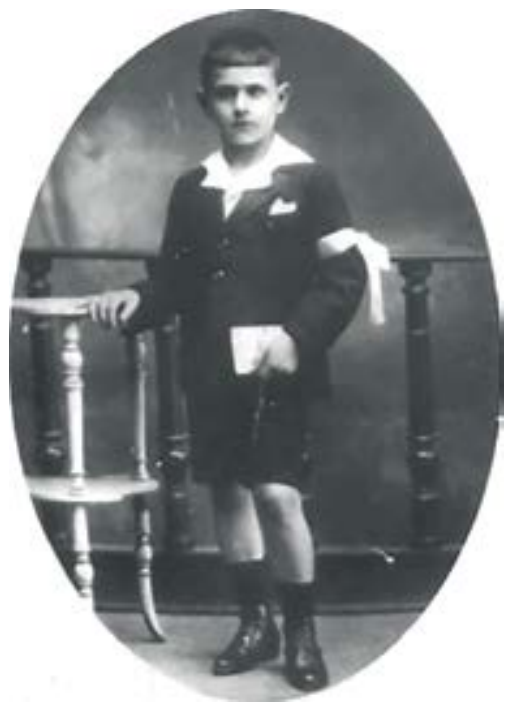

Fonte: arquivo pessoal do autor. 
Figura 17 - Curitiba, 1955

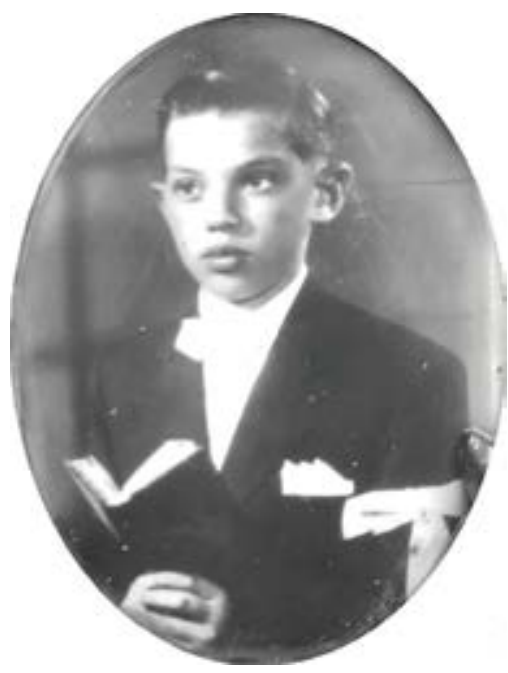

Fonte: arquivo pessoal do autor.

Figura 18 - Porto Velho, 1928

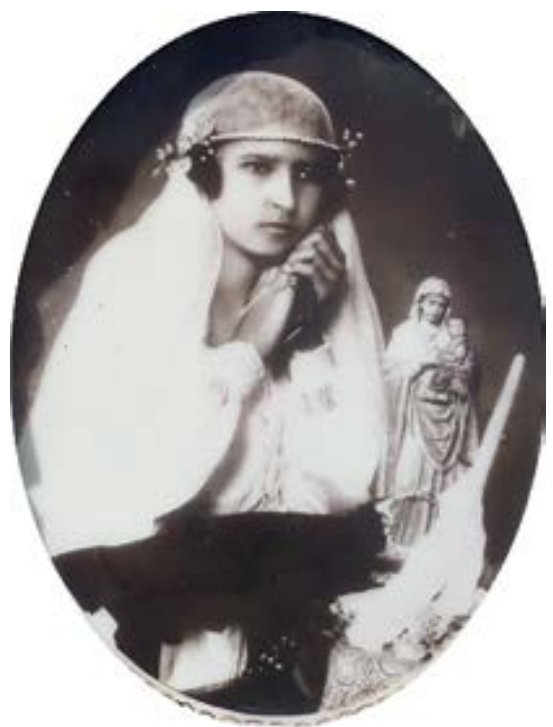

Fonte: arquivo pessoal do autor.
Figura 19 - Lembrança de Batismo em mausoléu

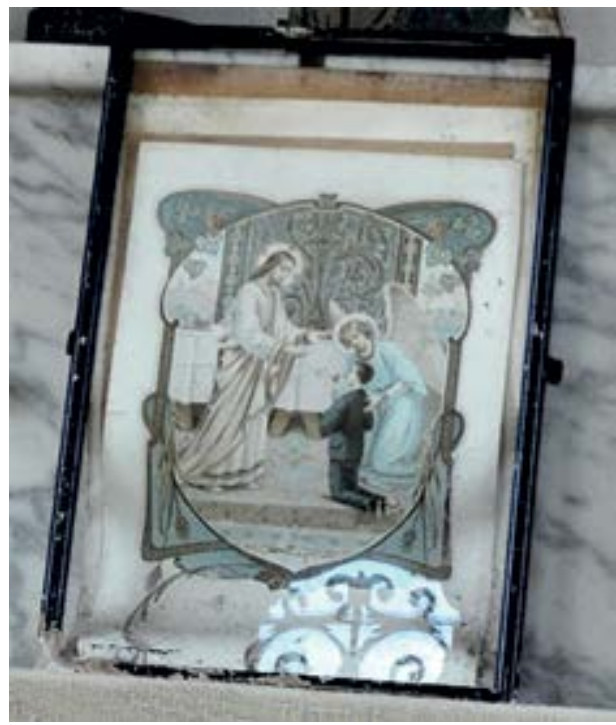

Fonte: arquivo pessoal do autor.

Mas a criança também pode ser apresentada dentro de um contexto familiar, ou seja, acompanhada do pai, da mãe, da irmã, do irmão ou todos reunidos. Em uma sociedade tradicional e religiosa, mostrar a família unida, amada, não deixa de ser um fato social dos mais relevantes. A Figura 20 apresenta a formalidade, uma pose tradicional dos fotógrafos de então. Sem toques, imóveis, sem esboçar qualquer reação, demonstrando hierarquias. A mensagem é mostrar a unidade e a felicidade familiar. A fotografia também apresenta uma questão importante para o período. Ter uma família grande era sinal de virilidade e fertilidade. Mas também havia a possibilidade da apresentação da família isolada em imagens, mas próximas no conjunto tumular, em especial quando as mortes foram em curto tempo. $\mathrm{Na} \mathrm{Fi-}$ gura 21, vê-se um casal e seus dois filhos. $\mathrm{Na}$ sepultura, duas frases do pai: "Saudade de 
seu filho B.J.Q." e "Lembranças de seu pai B.J.Q.". O pai morreu no ano de 1918, a mãe em 1915 e os dois filhos no mês de julho de 1913. Doenças que vitimavam famílias inteiras eram comuns naquela época.

Figura 20 - Rio de Janeiro, sem data identificada

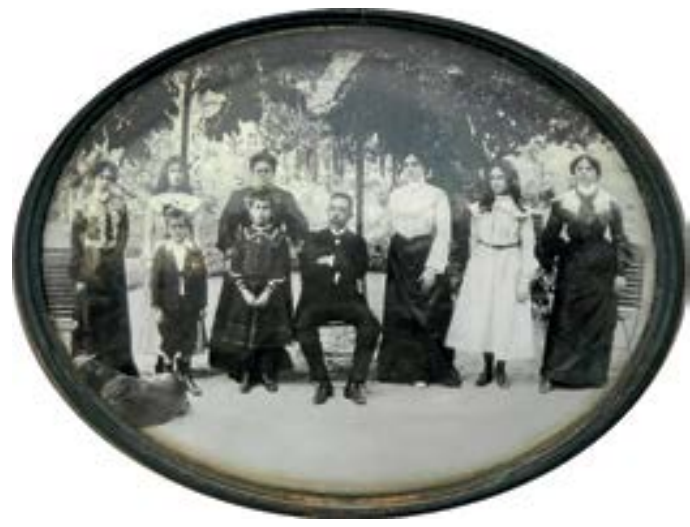

Fonte: arquivo pessoal do autor.

Figura 21 - Curitiba, sem data identificada

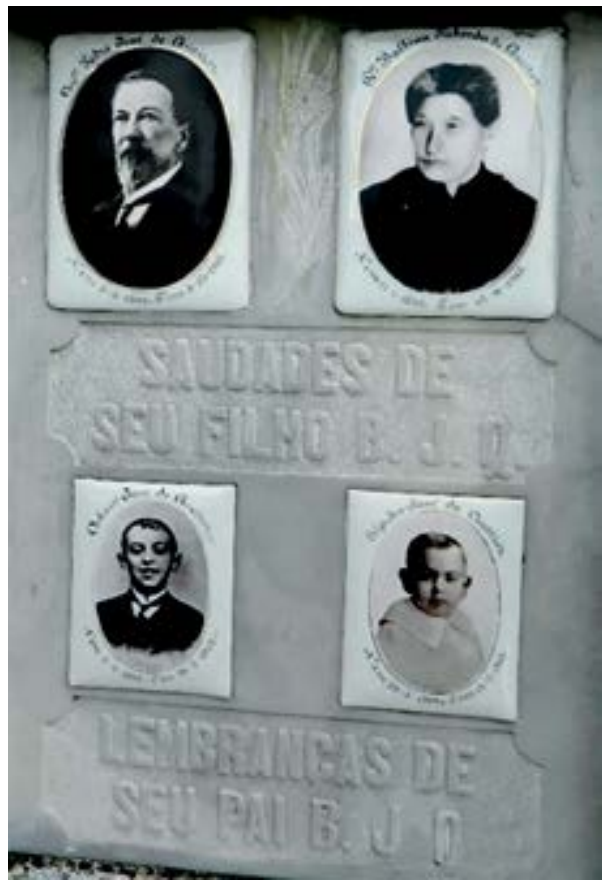

Fonte: arquivo pessoal do autor.
O padrão encontrado nos cemitérios pesquisados foi, como vimos, o da fotografia isolada, mas fotografias das crianças com a mãe não são incomuns. Recentemente, localizamos em cemitério de Asunción, por exemplo, uma fotografia de mãe e sua filha recém-nascida no mesmo caixão. Nada fora do normal a morte da mãe e do filho no parto. As Figuras 22 e 23, respectivamente, apresentam a fotografia de um jornal gaúcho, com a imagem de uma mãe e suas duas filhas, mortas em um acidente de avião em Porto Alegre, em 1950, e a placa em mármore com o relevo que reproduz a imagem. $\mathrm{Na}$ sepultura, abaixo da placa de mármore, uma expressão de dor do pai/esposo: "Quanta dor!... Quantas saudades!...". Chama a atenção a similitude da pose e das vestimentas. Trata-se do padrão de uma família de posses. A placa, diferente da fotografia, expõe contatos físicos, sorrisos, uma cumplicidade. Talvez um aprimoramento do artista (a pedido da família ou não) com base na fotografia para ornamentar o túmulo.

\section{Figura 22 - "Comove todo o Rio Grande a tragédia do 'Constellation"”}

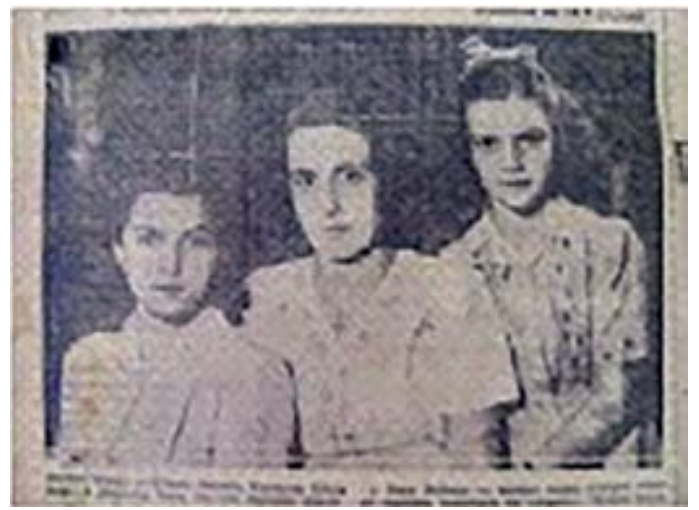

Fonte: <http://conselheirox.blogspot.com.br/2008/10/constellation-o-acidente-areo-que-matou.html>. 
Figura 23 - Rio de Janeiro, 1950

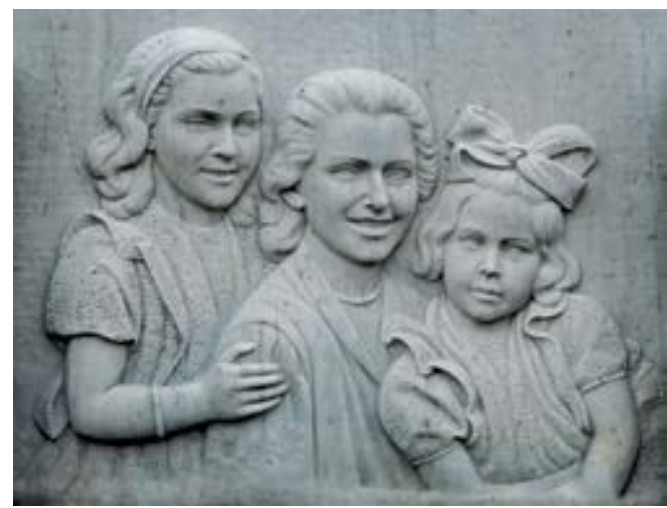

Fonte: arquivo pessoal do autor.

\section{Outras passagens}

As fotografias não eram de pouco custo, assim a seleção deveria ser rigorosa. Mais ainda quando fosse para serem adicionadas ao álbum de família. As passagens mais importantes da vida deviam ser lembradas e rememoradas com o tempo. Nas sepulturas infantis, esses momentos também estão presentes: a famosa foto do bebê com a bundinha para o ar, a primeira comunhão e o registro da morte. Embora muito presente nos álbuns de família, encontramos poucas fotografias na primeira pose em cemitérios, como essa do ano de 1925 (Figura 24).

Figura $24-1925$

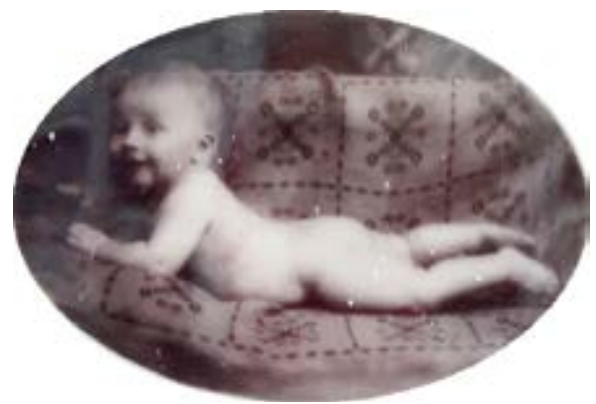

Fonte: arquivo pessoal do autor.
Crianças, em muitos cemitérios brasileiros, por sua condição de "anjos" ou "inocentes" e por representarem a pureza, tornam-se intercessoras (mediadoras entre o pedinte terrestre e Deus). Ao lado da famosa intercessora Maria Bueno, no cemitério de Curitiba, há o túmulo de uma criança, morta aos 6 anos de idade, que também se tornou intercessora. A Figura 25, apresenta a foto do túmulo da menina vestida em trajes de classe média/elite. Na Figura 26, pode-se observar as placas agradecendo às graças recebidas. Na mesma figura, as setas indicam a estátua de Maria Bueno (mais ao fundo, centro), acima de sua sepultura e bem à frente, na parede do cemitério, estão as placas com os agradecimentos pelas intercessões feitas e graças alcançadas (seta à direita). Por fim, a Figura 27 mostra a sepultura de um menino, repleta de flores, em fotografia tirada no Dia de Finados, que morrera atropelado em 1950, aos 9 anos de idade, em frente à catedral metropolitana, após fazer a primeira comunhão. Morrer em um momento tão especial transformou-o em uma criança intercessora. Seu túmulo, no cemitério de São Pedro, em Londrina, é o mais visitado no Dia de Finados.

Figura 25 - Fotografia de Eunice Ribas. Curitiba, 1929

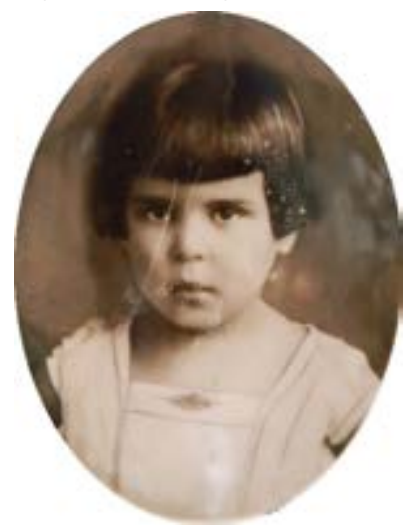

Fonte: arquivo pessoal do autor. 
Figura 26 - Vista do Mausoléu de Maria Bueno e de Eunice Ribas

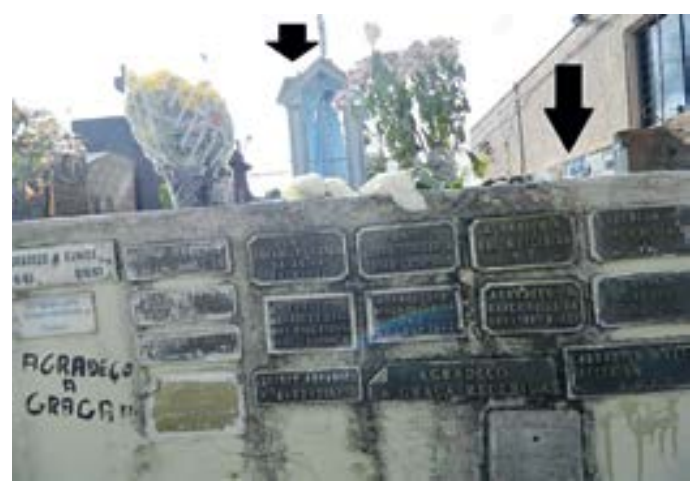

Fonte: arquivo pessoal do autor.

Figura 27 - Londrina, 1950

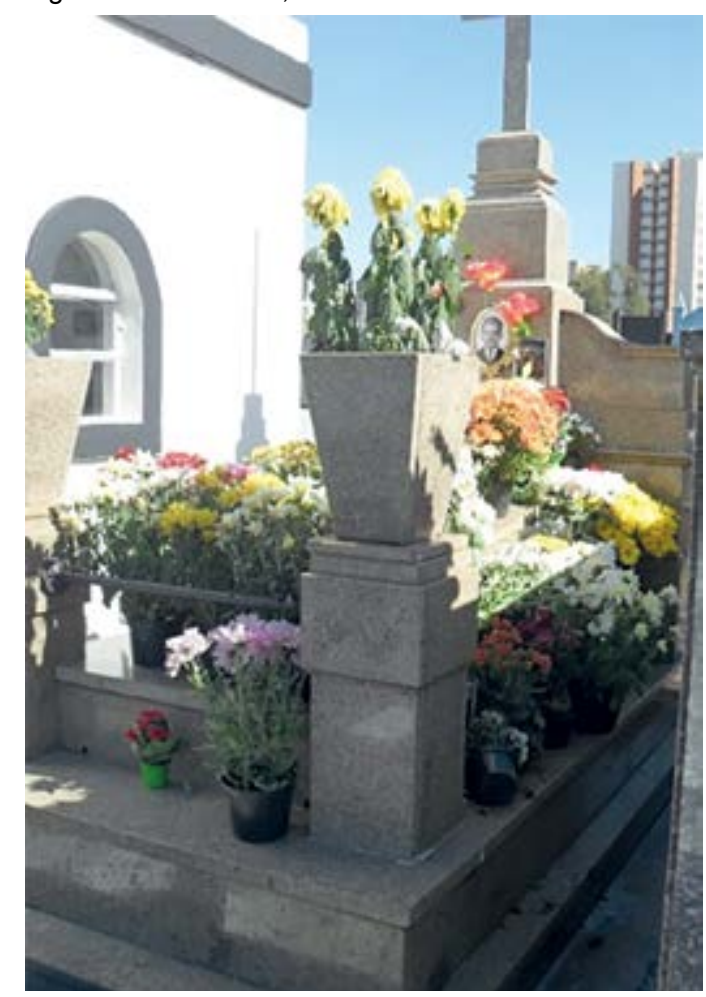

Fonte: arquivo pessoal do autor.

A seguir, apresentam-se algumas fotografias de crianças produzidas em estúdio. Evidentemente, os pais dessas crianças dis- punham de meios financeiros. Vê-se a pompa e a elegância, mesmo das crianças menores, caracterizadas pelas poses tradicionais - rostos sérios, sem sorriso - pelos modelos da vestimenta, imagens representando saúde. Mais uma vez as crianças são projetadas em seu meio, e não dentro de um caixão, vestindo uma mortalha. Provavelmente, até foram vestidos com a mortalha apropriada, com as mãos em oração, etc., mas a opção foi por outra imagem para compor a sepultura. Talvez pensassem, como muitos dos passantes, que as crianças eram inocentes e como tal já tinham o paraíso garantido e assim a imagem da criança vestida com a mortalha não seria para ornamentar o túmulo. Vemos a roupa de marinheiro e de corte militar para os meninos (de uso comum nas ruas e como uniforme escolar), para as meninas modelos distintos, muitos vindos da França, ricamente elaborados. Também é possível encontrar meninas vestidas com roupas pouco adequadas para o espaço sagrado do cemitério, como fantasias de carnaval, etc. (Figuras 28-33).

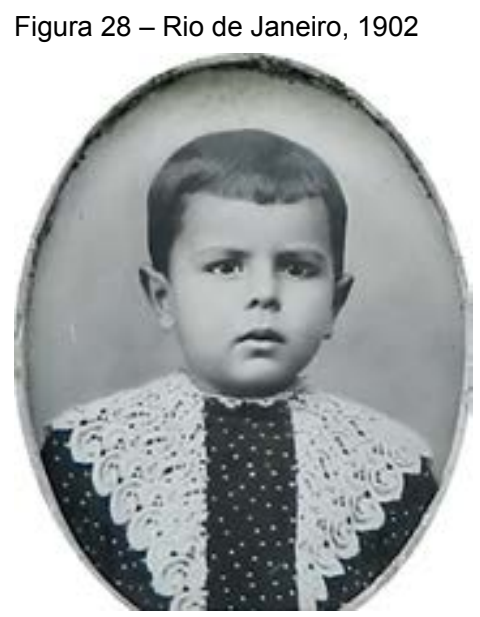

Fonte: arquivo pessoal do autor. 
Figura 29 -Curitiba, 1903

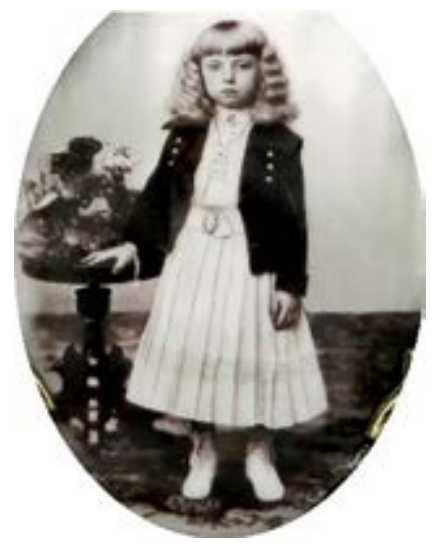

Fonte: arquivo pessoal do autor.

Figura 30 - Rio de Janeiro, 1912

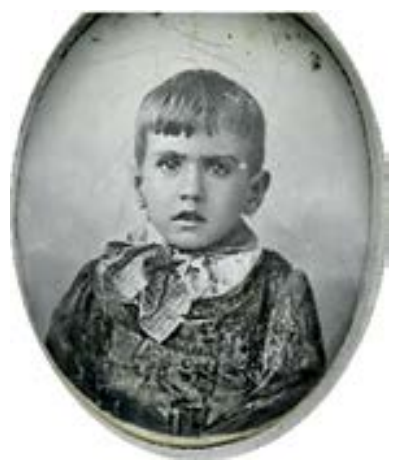

Fonte: arquivo pessoal do autor.

Figura 31 - Cáceres, 1913

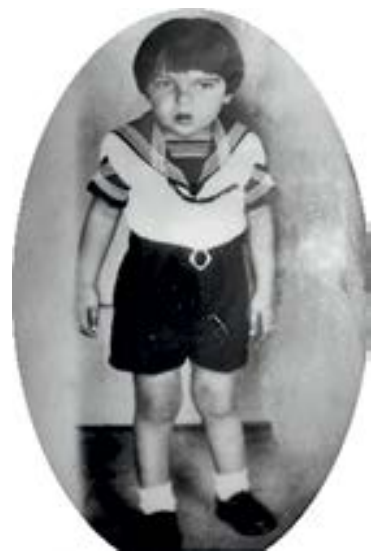

Fonte: arquivo pessoal do autor.
Figura 32 - Porto Alegre, 1939

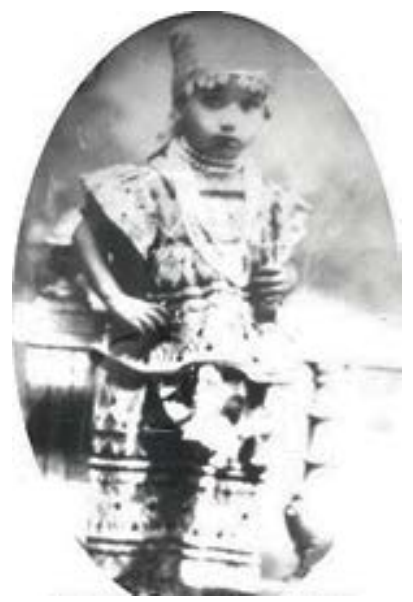

Fonte: arquivo pessoal do autor.

Figura 33 - Aracaju, 1940

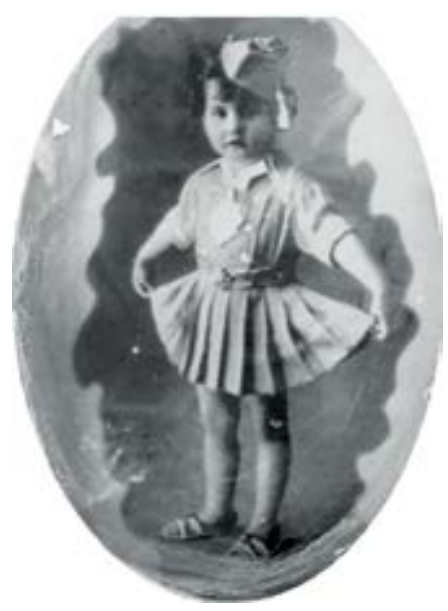

Fonte: arquivo pessoal do autor.

Ana Mauad apresentou diversas propagandas do século XIX de lojas da Corte, que anunciavam a possibilidade de comprar diversos modelos de vestimentas infantis. Sobre a adolescência, a autora escreve que: "Não existia uma roupa voltada para o adolescente, mas com 12 anos os meninos começavam a largar as calçolas e as meninas encompridavam os vestidos, assumindo gradualmente a 
maneira de vestir dos adultos" (1999, p. 144). A idade da inocência já teria passado, a malícia pode estar presente, a comunhão já fora realizada, assim, após os 12 anos, o uso do paletó e da gravata é comum. Isso pode ser observado nas próximas imagens, podendo-se perceber que o processo (modelo) se manteve no século XX, em que é possível visualizar essa característica. No caso da Figura 34, vê-se a imagem do jovem Hugo, falecido aos 11 anos de idade. Na campa, não cabia mais a inscrição de inocente. Agora a imagem que o representa deveria se assemelhar mais a de um adulto. Nesse sentido, não é incomum encontrar fotografias em que o filho se veste com a mesma roupa do pai, ou seja, é uma miniatura do adulto. Na Figura 35, Eucherio, de 13 anos, posou vestido como um adulto, de pé, sério, olhar fixo; sua idade é denunciada pela bermuda.

Figura 34 - Menino com paletó, São João Del Rey, 1929

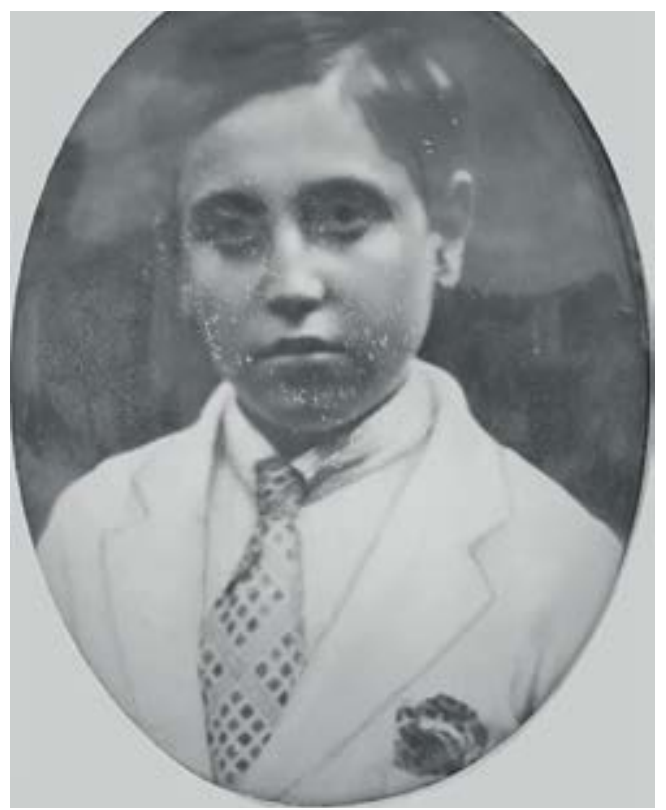

Fonte: arquivo pessoal do autor.
Figura 35 - Eucherio, Juiz de fora, 1926

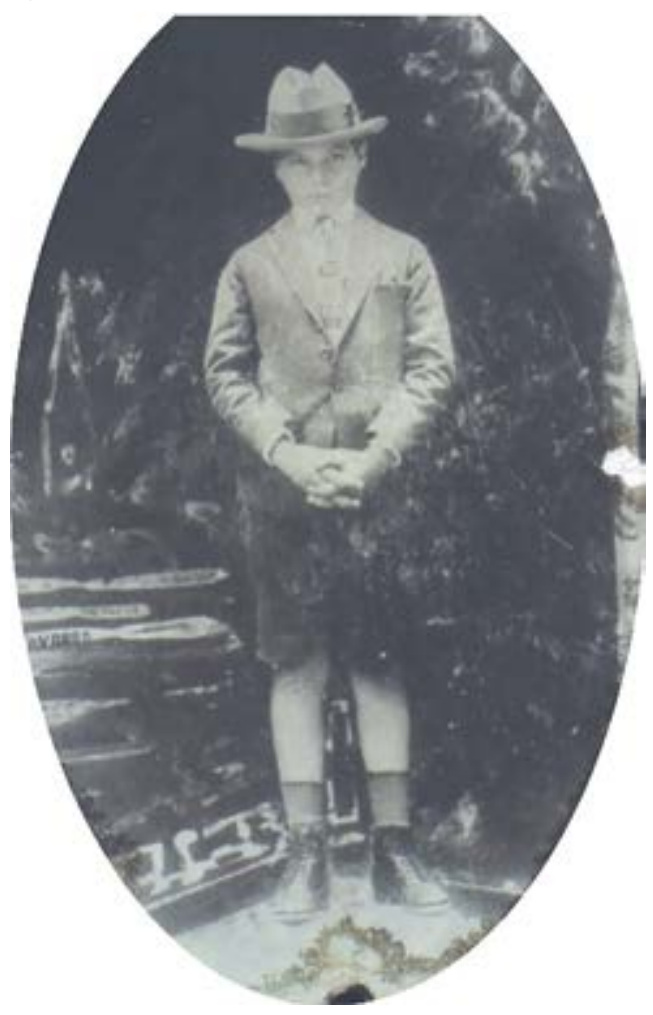

Fonte: arquivo pessoal do autor.

Por fim, mais alguns ornamentos cemiteriais. Ao longo deste texto foram apresentadas imagens representando a ida da criança (anjo) para o Céu bem como um relevo em mármore com a imagem da mãe e suas duas filhas, a seguir, observar-se-á mais quatro exemplos de estátuas representando a memória da criança morta. Nesses casos, trata-se de coisa pouco comum de se encontrar nos cemitérios devido ao alto custo de confecção.

A Figura 36 mostra uma mulher olhando para o devir, colocando as mãos sobre as cabeças de duas crianças: a menor (um menino) olha para a mulher e a outra (uma menina) para o céu, todos estão bem vesti- 
dos, conforme descrito por Mauad (1999): sapatos, meias, calça curta, em modelo marinheiro, para ele, vestido curto para a menina e vestido longo, escondendo todo o corpo (até o pescoço está coberto) para a mãe. Nas mãos, o menino tem uma flor e a menina segura uma coroa de flores (guirlanda). A leitura da lápide nos ajuda a entender a imagem construída: A filha morreu primeiro, em 1916, o menino depois (data ilegível) e, por fim, a mãe (sem data). Portanto, provavelmente, o viúvo deve ter encomendado a produção da peça para ornamentar o túmulo, talvez até substituindo uma estatuária.

Figura 36 - Mulher e duas crianças, Rio de Janeiro, sem data

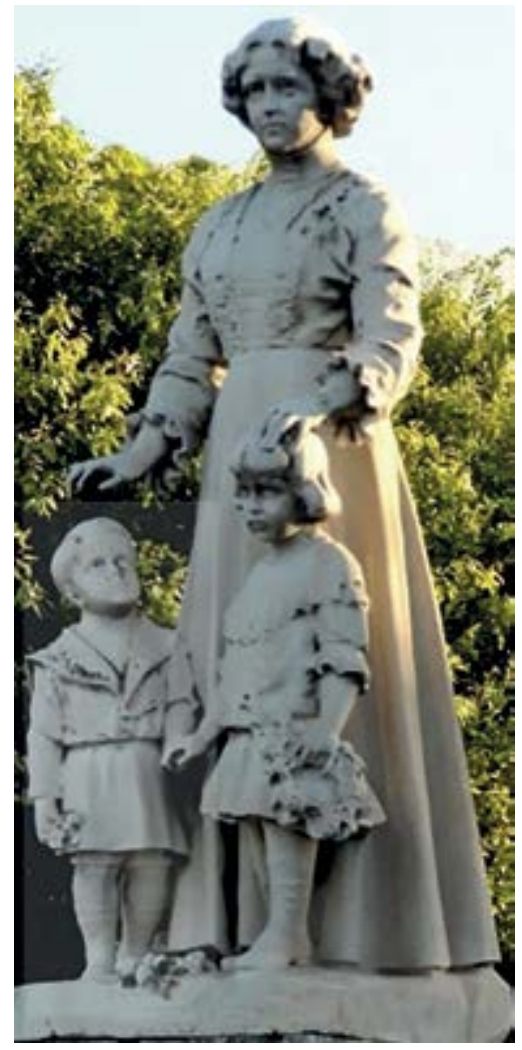

Fonte: arquivo pessoal do autor.
Na Figura 37, vê-se uma menina sentada em uma carteira escolar lendo um livro. Os pais desejaram representar a filha como se estivesse na escola (está até de uniforme). Explicitamente, apontaram a educação como fator de valorização da filha. Poderia estar sendo preparada para ser do lar e recatada, mas não analfabeta e inculta.

Figura 37 - Túmulo com escolar, Rio de Janeiro, 1928

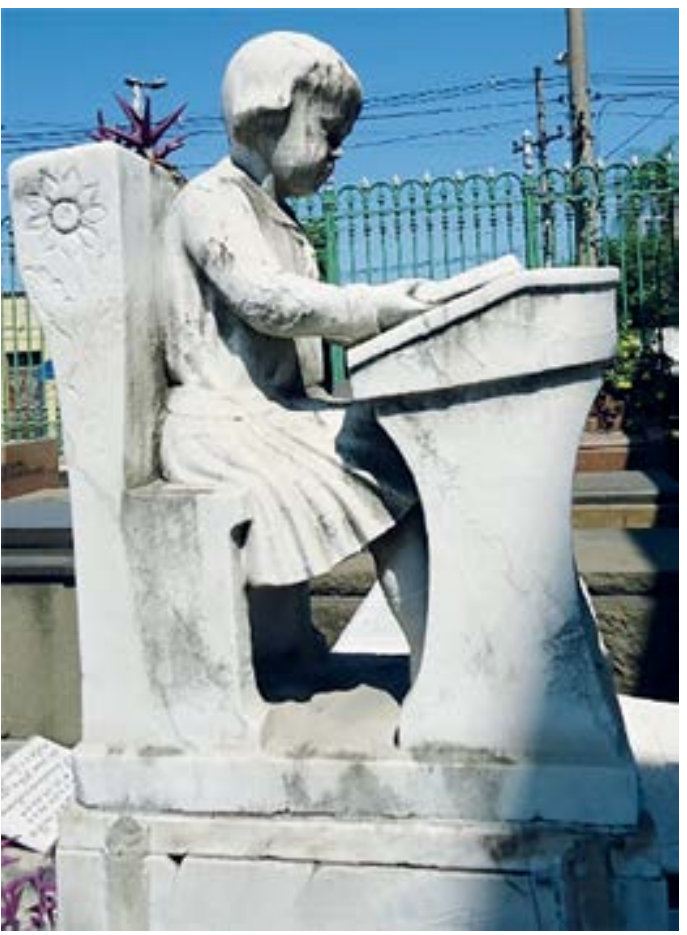

Fonte: arquivo pessoal do autor.

Em outra representação, a peça tumular é composta por duas crianças (meninas), uma em pé e outra sentada, a última segura em suas mãos um concha; aparentemente, a criança em pé é mais jovem do que a que está sentada. A sepultura é de uma criança morta aos 3 anos, uma "inocente", portanto, não há certeza de que a imagem retratada 
seja da falecida. As crianças aparentam ser brancas, com vestimentas simples e brancas e estão descalças (Figura 38). O símbolo da concha tem vários significados, um deles, o do batismo, muito próximo da morte da criança. Outro símbolo seria o da mãe de Jesus, pois a concha guarda sua pérola como Maria garda seu Filho. Infelizmente, não foi possível verificar a existência de uma pérola no interior da concha.

Figura 38 - Crianças com concha, Fortaleza, 1913

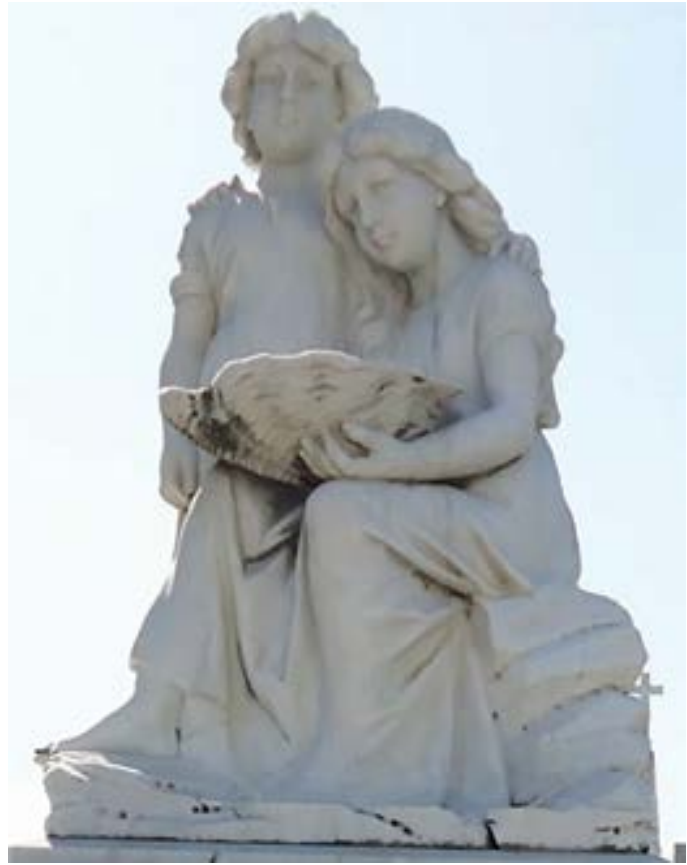

Fonte: arquivo pessoal do autor.

Por fim, na Figura 39, vê-se uma menina de alta classe social, devidamente vestida, com sapatos, meias, belo vestido, segurando rosas, uma, ela está depositando em seu próprio túmulo. Seu olhar se dirige para o observador.
Figura 39 - Menina com rosas, Rio de Janeiro sem data

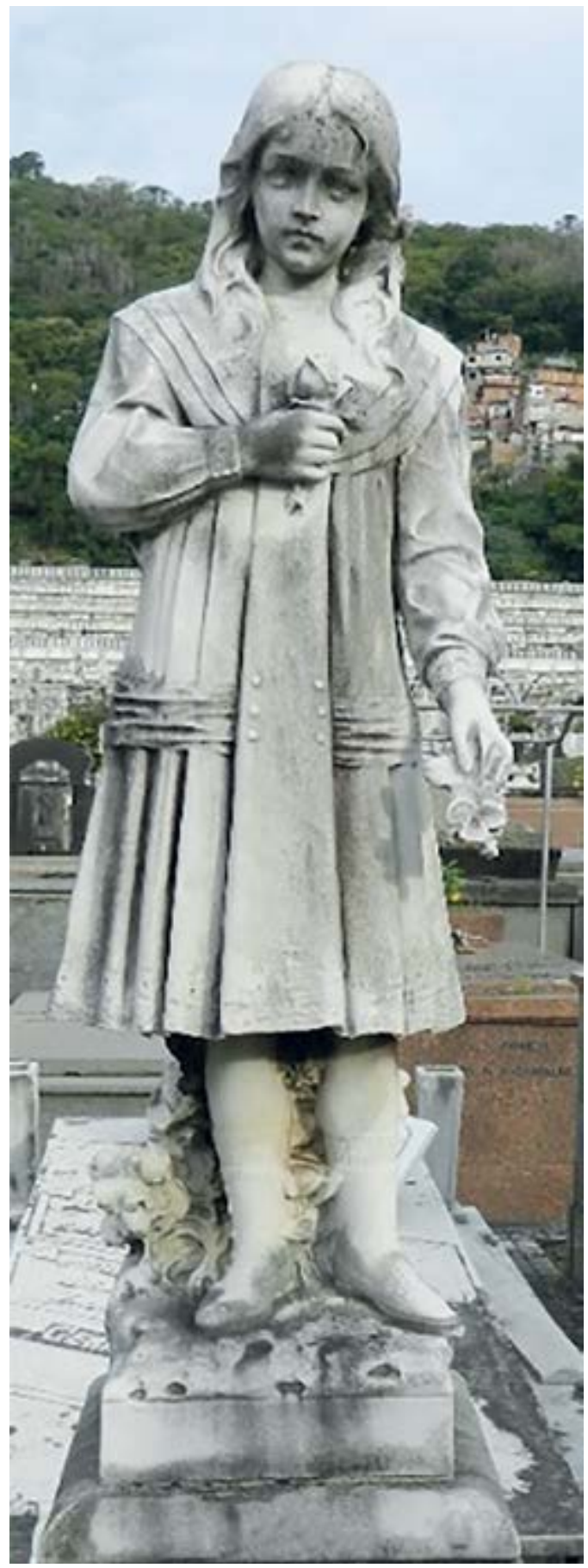

Fonte: arquivo pessoal do autor. 


\section{Observação final}

Há muitas opções de fotografias e várias abordagens poderiam ser feitas. Esse recorte atendeu aos objetivos considerados principais, verificar a representação tumular de crianças e sua afinidade com a religiosidade e os valores culturais. Registrar as mudanças no enfrentar/entender a morte, no espaço cemiterial, a possibilidade do uso da fotografia e de outros ornamentos nesse processo foi o intuito deste trabalho. Muito há por fazer, refletir e produzir nesse campo ainda muito fértil, mas pouco regado.

\section{Abstract}

The central question developed in this work was the use of images of children (photos and adornments) found in graves in cemeteries Brazil in the nineteenth and twentieth centuries. The use of photographs located in tombs still needs further research. The goal here is to enable the reader a historical approach on a specific topic, offer a perspective on the construction of the child's memory, either the images or the writings. The chosen cities are from different regions to assist in the demonstration of a possible pattern or an affinity with the theme of death. The cities where they are located cemeteries and dates of photos will be mentioned, but not the cemetery (where possible) or the family name of the deceased children.

Keywords: Ornaments. Cemetery. Children. Image.

\section{Resumen}

La cuestión central desarrollado en este trabajo fue el uso de imágenes de niños (fotos y adornos) que se encuentran en tumbas en cementerios brasileños en los siglos XIX y XX. El uso de fotografías ubicadas en tumbas todavía necesita más investigación. El objetivo aquí es permitir al lector una aproximación histórica sobre un tema específico, ofrecer una perspectiva de la construcción de la memoria del niño, ya sea en las imágenes o en los escritos. Las ciudades elegidas son de diferentes regiones para ayudar en la demostración de un posible patrón o una afinidad con el tema de la muerte. Se mencionarán las ciudades donde se ubican los cementerios y las fechas de las fotos, pero no el cementerio (donde sea posible) o el nombre de las familias de los niños fallecidos.

Palabras clave: Adorno. Cementerio. Niños. Imagen.

\section{Referências}

BARRETO, Lima. Clara dos Anjos. Rio de Janeiro: Ediouro, [1980?].

BORGES, Deborah Rodrigues. Registros de memória em imagens: usos e funções da fotografia mortuária em contexto familiar na cidade de Bela Vista de Goiás (1920-1960). Dissertação (Mestrado em Cultura Visual) - Faculdade de Artes Visuais, Universidade Federal de Goiás, Goiânia, 2008.

Variedades de história cultural. Rio de Janeiro: Civilização Brasileira, 2000. 
CARDOSO, Ciro Flamarion; MAUAD, Ana Maria. História e Imagem: os exemplos da fotografia e do cinema. In: CARDOSO, Ciro Flamarion; VAINFAS, Ronaldo (Org.). Domínios da história: ensaios de teoria e metodologia. Rio de Janeiro. Campus: 1997.

FABRIS, Annateresa. O circuito social da fotografia: estudo de caso $1^{\circ}$. In: (Org.).

Fotografia: usos e funções no século XIX. 2. ed. São Paulo: Universidade de São Paulo, 1998. (Coleção Texto e Arte, v. 3). p. 39-58.

KOSSOY, Boris. Fotografia E história. São Paulo: Ateliê, 2009.

Dicionário histórico-fotográfico brasileiro. Rio de Janeiro: IMS, 2002.

LAVELLE, Patrícia. O espelho distorcido: imagens do indivíduo no Brasil oitocentista. Belo Horizonte: Editora da UFMG, 2003.

LIMA, Tânia A. De morcegos e caveiras a cruzes e livros: a representação da morte nos cemitérios cariocas do século XIX. Anais do Museu Paulista (Nova Série), São Paulo, v. 2, p. 87-150, jan./dez. 1994.

MAUAD, Ana Maria. A vida das crianças de elite durante o Império. In: PRIORE, Mary Del. História das crianças no Brasil. São Paulo: Contexto, 1999. p. 137-176.

RODRIGUES, Claudia. Lugares dos mortos na cidade dos vivos. Rio de Janeiro: Prefeitura do Rio de Janeiro, 1997.

VAILATI, Luiz Lima. A morte menina: infância e morte infantil no Brasil dos oitocentos (Rio de Janeiro e São Paulo). São Paulo: Alameda, 2010.

VALDEZ, Diane. Filhos do pecado, moleques $e$ curumins: imagens da infância nas terras goyanas do século XIX. 1999. 216 f. Dissertação (Mestrado em História das Sociedades Agrárias) - Faculdade de Ciências Humanas e Filosofia, Universidade Federal de Goiás, Goiânia, 1999. 